\title{
SAINT FRANCIS OF ASSISI - GREGORY SKOVORODA - BOHDAN-IGOR ANTONYCH: TANGENCY OF WORLDVIEWS
}

\section{Dmytriv I. I.}

\section{INTRODUCTION}

Bohdan-Igor Antonych holds an exceptional place in the history of Ukrainian literature thanks to his exceptional poetic talent, as well as his deep and original worldview, which can be impossible inserted in a certain canon or find analogues to him. However, analyzing the poetic heritage of the artist, we observe interesting parallels with the Christian outlook of St. Francis of Assisi and the life philosophy of Gregory Skovoroda. Of course, this is not about any imitation, but rather about the nearness of views on God, the Scriptures, and the world around of people exceptionally talented and sensitive to the grace.

Saint Francis of Assisi is one of the most famous saints of the Catholic Church, who lived in 1181 - 1226. His holiness consisted of the unconditional service of the "Madonna of Poverty", a constant penance, selfless love for everything created by the Lord. Joseph Ratzinger says that through the work of St. Francis, Christ went down to history in a new way, in a new way showed his word and his love, renovated his Church, and directed history to himself ${ }^{1}$.

Gregory Skovoroda is the most outstanding figure of the Baroque period in the history of Ukrainian literature. According to S. Pogoriliy, the philosopher was too great for his era, because he had been ahead of it for several centuries ${ }^{2}$. However, as scientists rightly remark, he remained the spiritual axis of Ukrainian culture forever. The great interest to the person of Gregory Skovoroda confirms the idea that he is perceived as a certain archetype of the Ukrainian nation, in which its characteristic features were embodied. Based on this, it is necessary to retrace the "worldview presence" of Gregory Skovoroda in the artistic texts of his followers, specifically in the works of Bohdan-Igor Antonych.

1 Рацінгер Йосиф (Венедикт XVI). Ісус з Назарету. Книга друга. Від в’їзду в Єрусалим до Воскресіння / Пер. з нім. І. Терзової. Жовква: Місіонер, 2011. Ст. 274.

${ }^{2}$ Погорілий С. Символи у Сковороди. Сучасність. 1973. Ч. 3 (147). Ст. 17. 


\section{Nature as a source of God-knowledge in worldview of St. Francis of Assisi and Bohdan-Igor Antonych}

The attitude of St. Francis to nature, which, in his opinion, bears the seal of the Creator, particularly attracts attention. He described the beauty of creatures with a considerable poetic ability in the work "A hymn to the brother Sun".

Reverence worshiping to the Creator and merging, identifying oneself with nature, are observed in the works of Bohdan-Igor Antonych, because of which many researchers are trying to involve him into the frames of pagan worldview. But, as already noted, Ivan Ohienko, Mykola Ilnytskiy, Iryna Betko and other literary critics explain the pantheistic nature of B.-I. Antonych's worldview in that he was born in the picturesque Lemkivshchyna region, so the beauty of nature and the whole environment became for him one of the means of the knowledge of God and the worship of God.

Paul Tillich writes about nature as a means of Revelation: "There is no reality, thing or event that could not be the bearer of the mystery of being and which could not enter into anout spoken correlation"3. The joy of communicating with nature in Antonych does not go into the objection of a single God - on the contrary, confirms his oneness, because he speaks to the soul about the Great harmony created by one hand. Anna Tokman believes that this was deceiving many researchers, who, considering excessive life-love and admiration of nature as a privilege of paganism, tended to interpret Bohdan-Igor Antonych as a pagan ${ }^{4}$.

In favor of the fact that Antonych's reverence before nature should not be ascribed to paganism, there are the examples from the lives of many saints of the Eastern and Western Churches, for whom the world around is a perfect creation of the hands of God, even the psalmist exclaims with inspiration: "O Lord, how great is the number of your works! in wisdom you have made them all!" (Ps. 103, 24). On this occasion, Vasyliy the Great says, "Believing to Moses that God made heaven and earth, let us glorify the best Artist who created the world wisely and artistically, and from the beauty of what we have seen, we will comprehend Him Who exceeds all by beauty and in the greatness of His power exceeds any

\footnotetext{
${ }^{3}$ Тиллих П. Систематическое богословие. СПб.: Алетейя, 1998. Ст. 130.

${ }^{4}$ Токмань Г. Збірка Б.-І. Антонича “Велика гармонія" у діалозі з екзистенціальним богослов’ям. Слово $i$ час. 2002. № 12. Ст. 43.
} 
understanding",5. However, only a person transformed, renewed in the Holy Spirit, is able to feel the original harmony of the Garden of Eden. One of the most eloquent examples of such a subtle world-feeling is the phenomenon of St. Francis of Assisi, about which Maria Sticko writes that he had the gift of seeing beauty and was able to enjoy it when he was still a layman, but then he was consoled and attracted only by exquisite and precious things. Only after a great renunciation he began to understand the beauty of nature, which had previously been admired only superficially. After his conversion, he began to see God's seal in every thing: the tree meant the cross for him; the stone - Jesus Christ, called the cornerstone in Scripture; water has always meant the Lord, because it comes from the source of eternal life; the sun also reminded him about God, because it is a symbol of justice ${ }^{6}$.

The symbolic vision of the world did not at all force out the real view on things. It improved it, made it more sensitive and deeper, because the look no longer stopped in appearance, but went deep into the origins. This had important consequences. First, Francis understood that creatures were not a source of temptation for him, as for the many ascetics who lived before him, but the creations of God who continually return man to the Creator. Secondly, Saint Francis, who, even in animals, plants and stones, was able to see the creation of the Father of all things, never thought about them as inferiors, but considered them brothers and treated them with love and respect, so they spoke with him in the name of God. "His soul, purified by the repentance and elated by love, got the right to reign over the nature that Adam used in earthly paradise and lost through sinning. All living in their innocence submits the man who has become sinless again" ". The love of creations was a manifestation of love for God the Father, in which human life becomes meaningful.

On this occasion E. Ronki thinks: "The humble joy of life, filled with gratitude and respect for persons and things whose name is marked with the seal of Beauty, enables us to enjoy life, to fill us with not pagan but religious joy. It all becomes the glory of the One who made things good. It becomes the first Liturgy which will always last [...] To become a part of

5 Творенія иже во святихъ отца нашего Василія Великаго, Архіепископа Кесаріи Каппадокійскія. У 3 т. Т. 1. Санкт-Петербургъ: Книгоиздательство П. П. Сойкина, 1911. Ст. 13.

${ }^{6}$ Стікко М. Святий Франциск з Асижу / Пер. $з$ італ. Н. Липки. Жовква: Місіонер, 2010. Ст. 205.

${ }^{7}$ Стікко М. Святий Франциск з Асижу / Пер. з італ. Н. Липки. Жовква: Місіонер, 2010. Ст. 206. 
an authentic and personal meeting with God, it is not enough doctrines, which are born of catechesis - the power of attraction, exaltation, and joyful enthusiasm are required, both in love and in joyful exclamation: "What a beauty!". Otherwise, dry doctrines will only give life to sadness, coldness, estrangement, and an icy heart. [...] The poet's line is a windowprophecy through which you see eternity, through which you see something greater than our world, something deeper and more beautiful; the world is not a simple collection of facts, it is an open book, the future, Eden, which is entrusted again to those who will take care of it and promote its prosperity. As the land belongs to those who feel its beauty and make it better (B. Brecht)" ${ }^{\prime 8}$.

A few years before his death, St. Francis felt the need to present his "epilogue of life" verbally, in which his life position would be set forth authentically, from the first mouth. Thus the hymn to the Lord's creations was created, which is also valuable in that it is written by a sick, poor man in extremely difficult circumstances.

The Most High, Almighty, the Kindest Lord,

You are to have praise, glory, honor and all blessings.

Be glorified, my Lord, with all Your creatures, especially with the brother Sun,

which warms us up and makes us happy to Your glory.

He is beautiful, radiant in a bright nimbus -

It is Your reflection, the Most High.

Be glorified, my Lord, for the brother Moon and for the daughters Stars;

You made them bright and beautiful in the sky.

Be glorified, my Lord, and for the Wind, and the Rain, and the clear Day, and for every weather that gives your creatures nutrition.

Be glorified, my Lord, for our sister Water, that is so useful, humble, precious and pure.

Be glorified, my Lord, for the Fire by which You enlightens not a starry night because it is beautiful, joyful and strong.

Be glorified, my Lord, for our mother Earth, that feeds and grows us, bears different fruits, colorful flowers and herbs ${ }^{9}$.

"To appeal to the lower creatures in such way", writes Maria Stikko, "one had to penetrate into the mystery of their lives and break the

${ }^{8}$ Ронкі Е. Закоханий і здивований Бог / Пер. з італ. К. Зінченко. Львів: Свічадо, 2015. Ст. $31-35$.

9 Цит. за: Стікко М. Святий Франциск з Асижу / Пер. $з$ італ. Н. Липки. Жовква: Місіонер, 2010. Ст. 279. 
contrasting between nature and God, between matter and spirit" ${ }^{\prime 10}$. Later, St. Francis supplemented this work with praise music, body, death, Motherland.

The way to love God and his creation was new in the Christian worldview of St. Francis. The pagan world loved only creatures, the Old Testament world loved God, but by slave love, the Christian world loved God already with son love, but often neglected his creatures, feared them as temptations, because he had not yet matured to a new gospel view of nature. However, Saint Francis did not identify creations with God in any way; he simply "was able to enter into communion with the created things with the human compassion that is inherent to poets and with the divine compassion that is inherent to Saints" ${ }^{\prime 1}$.

The poetic creative work of B.-I. Antonych may serve as an artistic illustration of the Francis Assisi's postulates, because he is the author of "Hymn to Life", and works from the collection "The Great Harmony" "Deus Magnificus" ("God Magnificent"), "Te Deum Laudamus" ("We Praise Thee, O Lord"), "Magnificat" ("Glorification") should be considered as the only great glory-word of divine omnipresence:

On the highest crests of mountains - is He, on the deepest bottom of the sea - is He,

in the sky, in the chambers of mountains - is He, in every night, in every day - is He.

You hear Him in the rustle of wind and the gurgling foam of the sea, everywhere, He is everywhere - Great and Indivisible ${ }^{12}$.

By the way, B.-I. Antonych is often using an anaphor for the imagery and rhythm of the text, as well as for the combination of structural elements of the work, for example:

For You the sea plays a radiant, spirited psalm,

for You the wind sings echoing, thunderous songs,

for You the fierce storm disturbs the bottom of the sea, for You the grass stirs in a silken whisper ${ }^{13}$.

In Francis of Assisi, the refrain "Be glorified, my Lord!" is a unifying element.

${ }^{10}$ Стікко М. Святий Франциск з Асижу / Пер. 3 італ. Н. Липки. Жовква: Місіонер, 2010. Ст. 281.

${ }^{11}$ Стікко М. Святий Франциск з Асижу / Пер. $з$ італ. Н. Липки. Жовква: Місіонер, 2010. Ст. 282.

12 Антонич Б. І. Повне зібрання творів / Передмова Миколи Ільницького; Упорядкування і коментарі Данила Ільницького. Львів: Літопис, 2009. Ст. 92.

13 Антонич Б. І. Повне зібрання творів / Передмова Миколи Ільницького; Упорядкування і коментарі Данила Ільницького. Львів: Літопис, 2009. Ст. 112. 
In Francis of Assisi and Bohdan-Igor Antonych we retrace common features in the perception of Jesus Christ. In the poetry "The Lamb of God", Christ is symbolized in the image of the lamb, which has an ancient biblical tradition (the prophecies of Jeremiah, "But I was like a gentle lamb taken to be put to death" (Jer. 11, 19), Isaiah "Men were cruel to him, but he was gentle and quiet; as a lamb taken to its death, and as a sheep before those who take her wool makes no sound, so he said not a word"(Isa. 53, 7). The Lamb is an animal of extraordinary gentleness and humility; it is on the basis of this similarity that this image-symbol is used to mark Jesus Christ - the Immaculate Lamb of God, who takes the sins of the world upon himself to redeem them with the price of His own blood. About Francis of Assisi is mentioned that the lambs had caused him special tenderness; he did not consider them foolish, but saw the gentleness and obedience in them -features inherent in Christ Himself ${ }^{14}$. Therefore, as in the perception of St. Francis of Assisi and Bohdan-Igor Antonych God, merciful and gentle, not fair and punishing, is at the forefront. God's love and longsuffering serve Christians as an attractive force that cause admiration of God. Such relationships between the Creator and creation have a much more optimistic perspectives than those built on the compulsion and fear of being punished for every violation of the law. A personal connection with God gives birth to joy, a hope that is the attainment of the great saints, including Francis of Assisi. Most Christian works of Bohdan-Igor Antonych are pierced with light tonality and optimism ("Ut in omnibus glorificetur Deus", "Te Deum laudamus", "Veni Sancte Spiritus", "Gloria in excelsis", "Magnificat", etc.), sadness in the lyrical is only when he, having a delicate conscience, feels guilty that succumbed to the exhortation of the devil-tempter and wounded by the sin the most perfect love of God (for example, the poems "Apage satanas", "Confiteor").

For B.-I. Antonych everything that exists outside of God is darkness. And only Christ is "eternal light for eyes", "early enlightenment in the darkness", "song of the sun and clear day". St. Francis of Assisi was also most admired with light, as always with a new miracle - the light of the sun, the light of fire, and said that every morning, as soon as the sun came up, all creatures should glorify the God who created it for us ${ }^{15}$.

"The Book of the Lion" by B.-I. Antonych is anoriginal reactualization of the books of the Old and New Testaments with special emphasis on the

\footnotetext{
${ }^{14}$ Стікко М. Святий Франциск з Асижу / Пер. з італ. Н. Липки. Жовква: Місіонер, 2010. Ст. 203.

15 Стікко М. Святий Франциск з Асижу / Пер. з італ. Н. Липки. Жовква: Місіонер, 2010. Ст. 204.
} 
act of creation of the world. In "The Ballad about the Prophet Jonah", with the help of a lyrical hero the poet tries to penetrate into the mystery of being, to find the definition of beauty and the ugly, to understand the meaning of what goes beyond human logic. Prophet Jonah has a worthy mission - to be the spokesman of "The one who frees the sun from the night of the ice", "The one who casts winds from the palm of his hand", "The one who extinguishes the nights and shines the candles of days", "The one who creates and destroys the worlds" and to call all the inhabitants of the deep abyss to glorify the Lord. That's why, the prophet Jonah is one of the prototypes of Jesus Christ: as Jonah was in the belly of the fish for three days and visited the deep abyss, so Christ was in the tomb and went down to hell to bring salvation and to present the dignity of God's children to all prisoners since Adam's time. St. Francis of Assisi fulfills a similar mission, however "from the height of divine love he goes back to the creatures again, feeling the most touching tenderness for them, he is looking at them, admiring them, fondling their by eyes, as if saying to fire, water, the stars and the herbs: "You do not know what a wonderful creature you are! But if so, I'm telling you this! You deserve admiration - I give it to you. You have no consciousness - I have it, and for you I praise and thank Him who created you, as He created me, because in Him you are my brothers and sisters"

\section{The main aspects of Christian God-thinking of Gregory Skovoroda and Bohdan-Igor Antonych}

Gregory Skovoroda and Bohdan-Igor Antonych lived and worked in different time and cultural periods, but between them there is a certain spiritual connection, which is traced in similar views on God, the world, man, nature. Themes of soul's peace, harmony, death were favorite for both poets. Some poetic works of artists are related even by genre, because it is known that the poems, which were included in the collection "The Garden of Divine Songs", G. Skovoroda called "songs", and in B.I. Antonych is a series of works that the author has marked as "songs".

God and the Bible is the worldview reliance of Gregory Skovoroda. The thinker is convinced of that "everything lives and moves in God and by the power of God, we know everything only through God and in God", "God penetrates and holds all creation", "God is in our human body - one and the same in any and whole in each of us" $"$. According to the

\footnotetext{
${ }^{16}$ Стікко М. Святий Франциск з Асижу / Пер. з італ. Н. Липки. Жовква: Місіонер, 2010. Ст. 281.

${ }^{17}$ Чижевський Д. Філософія Г. С. Сковороди / Підготовка тексту, мовна редакція та вступна стаття Л. Ушкалова. Харків: Акта, 2003. Ст. 182.
} 
philosopher, the Bible is "created by God from holy and mysterious images", it is "the most perfect and wise organ", "the new world and new humanity of God, the land of the living, the land and kingdom of love, the high Jerusalem"18. That's why, "The Garden of Divine Songs" is "flourished from the grains of Scripture".

Bohdan-Igor Antonych's "The Great Harmony" also contains numerous allusions and reminiscences from the Scripture.

In the titles of "The Garden of Divine Songs" and "The Great Harmony" we trace a certain joint rod. In the poetic collection of Gregory Skovoroda, the garden is an orderly, well-groomed place where beauty and harmony reign. Of course, there is an allusion to the Garden of Eden God's perfect creation, a place where man was happy. Symbolically, the garden is a human soul, purified of passions, in which the Holy Spirit breathes in full force and the talents, which she skillfully uses, laid down by God sprout: "The soul of ego is God's hail, the soul of ego is God's garden" "19. However, only the person, who makes efforts for the refinement, aesthetization of his garden-soul, can expect fruits from him, so Gregory Skovoroda rightly calls the Bible the guide in the spiritual life.

So, "The Garden of Divine Songs" and "The Great Harmony" are collections of spiritual lyricism, because the search for a deep personal connection with God, the experience of which is comprehended through the Scripture and the Liturgy, is a leading theme in them.

The common point of contact between the two artists was the "philosophy of the heart", which was theoretically substantiated by Gregory Skovoroda, and Bohdan-Igor Antonych offered its artistic reception in his poetic collections. In the Scripture, the heart occupies one of the central places, it is ascribed to the fullness of the spiritual life, because all the functions of consciousness are connected with it. In the biblical texts, "heart" means not one of the properties of the soul, but of the whole person, the integrity of all its properties and the general attitude to others, to God, to the world. When in the Scripture is mentioned that we must love God "with all our heart," it means "with all thy soul, and with all thy mind and with all thy strength" (Mt. 22, 37; Mk. 12, 30; Lk. 10, 27).

According to Gregory Skovoroda, the heart is a "divine spark" in man, so the path to the comprehending of transcendental lies through the heart. Analyzing the specificity of the spirituality of the Christian East, Thoma Shpidlik writes: "To see God in all things" - in such words, the Eastern authors define Christian contemplation [...] Each person aspires to see the

\footnotetext{
18 Чижевський Д. Філософія Г. С. Сковороди / Підготовка тексту, мовна редакція та вступна стаття Л. Ушкалова. Харків: Акта, 2003. Ст. 115 - 116.

${ }^{19}$ Сковорода Г. Світ ловив мене, та не впіймав. Харків: Фоліо, 2006. Ст. 513.
} 
reality that she has to deal with. However, you can see in differently. First of all, with the help of eyes. But we will not see God because He is invisible. Intellect that formulates clear ideas and abstract concepts allows us to see at a much higher level. But even in this way it is not possible to reach God, because He goes beyond what the human mind is capable of. But still Christ promised us the opportunity to see God: "Happy are the clean in heart: for they will see God" (Mt. 5, 8) ${ }^{20}$.

The heart in Christian spirituality is not only a way of comprehending the Divine, but a place of meeting of God and man. Such an understanding of the heart is characteristic to the poetic creative work of B.-I. Antonych, specifically, in the poem "Two Roads", the lyrical hero tells us that he looked for God everywhere: in the lowlands, in the mountains, in rich houses and libraries, he made inquiries about him in the winds and passersby, but they could not meet because God looked for him in the heart. St. Augustine, having experienced this experience, states: "Lord, I did not find you outside, but you were inside me" religion is a personal relationship with God, then the connection with the Divine cannot exist anywhere but in the depths of my "self", in the depths of the heart, because, as Pascal says, we feel God by our heart"

G. Nasminchuk fairly notices that the poem "Two Roads" by ideological planis an apology of search. A characteristic feature of this poem is that all tropes gravitates to something mystical, for example, "dim twilight", "dusty libraries", "dead mold". Researchers of creative work of B.-I. Antonych was repeatedly asked the question: Where is such gloom, disappointment, even doom from? However, in the poem "Glory in the Highest", the author wrote that he wants "To embrace all people with great, bright joy", he wants "To laugh carefree, happily" and "To clap in your palm Like a little child". In spite of that by the time of writing poems are settled down side by side, when they are compared, a completely different tonality throws into the eyes. According to G. Nasminchuk, this witnesses to the fact of the polyphonism of Antonych's belief in $\mathrm{God}^{23}$, and there are many such evidences in "The Great Harmony".

So, in the poem of B.-I. Antonych "Two Roads" the lyric hero failed to meet God, and let's try to understand why. First, we learn from the work

${ }^{20}$ Шпідлік Т. Мистецтво очищувати серце / Пер. з італ. А. Маслюх. Львів: Свічадо, 2005. Ст. 63.

${ }^{21}$ Іспит сумління з учителями християнської духовності / Пер. 3 пол. О. Мандрика. Львів: Свічадо, 2014. Ст. 8.

22 Шпідлік Т. Мистецтво очищувати серце / Пер. $з$ італ. А. Маслюх. Львів: Свічадо, 2005. Ст. $65-66$.

${ }^{23}$ Насмінчук Г. Біблійна естетика у творчості Б.-І. Антонича. Біблія $і$ культура: Збірник наукових статей. Вип. І. Чернівці: Рута, 2000. Ст. 83 - 84. 
that the lyric hero is outside of heart, "wanders", as the poet writes. The Lord loves an attentive heart, only then He can appear. "God is hidden and is in the soul, and that is where the contemplative man should look for Him, asking, "Where are you hiding yourself?"24 Secondly, the "questioning about God" detail is also important because it proves that the lyric hero is trying to reduce the knowledge of God only to the intellectual, wishing to adopt another's experience of God-knowledge. The personal connection, which is carried out in the heart, is important for the Lord. Third, to feel that God visited man can only those who are "pure in heart," so the psalmist says, "Create a pure heart in me, o God". The theme of purity of heart is also reflected in the poetry of Gregory Skovoroda: "He who is pure in heart and in soul, does not need that armor [...] God himself is his shield, sword, and helmet" ${ }^{25}$. Perhaps, at that time the strings of the lyrical hero's heart from the poetry of B.-I. Antonych, was not tuned to the perception of grace, but the poet still had the experience of such a divine visits, as evidenced by the mood of many poems in the collection "The Great Harmony".

The purity of the heart in both artists is often associated with the theme of death. Gregory Skovoroda teaches that only the pure heart has no fear of thunder and lightning, and in the popular 10th song declares that the one who has a clear conscience is not afraid of death:

Terrible death, an encroaching scythe!

You do not spare the royal hair,

You don't look where is the simple man, and where is the king -

You devour everything like fire a straw.

Who spits on its sharp steel?

The one whose conscience is like pure crystal ${ }^{26}$.

In the Christian sense, death is a great mystery, not the end, but the beginning of a full life in God, it is the entrance to paradise, the door to which Christ opened by his death and resurrection. St. Apostle Paul speaks about death as great bliss: "For to me to live is Christ, and to die is gain" (Phil. 1, 21). B.-I. Antonych was destined to finish earthly life at a very young age. All his poetic creative work is imbued with thanatology images, symbols, visions, which are anoriginal artistic continuation of Skovoroda's philosophical and poetic reflections about death.

It is noticeable that both G. Skovoroda and B.-I. Antonych clearly distinguishes the concepts of "spirit", "soul", "heart". In the Ukrainian

${ }^{24}$ Іспит сумління з учителями християнської духовності / Пер. 3 пол. О. Мандрика. Львів: Свічадо, 2014. Ст. 8.

${ }^{25}$ Сковорода Г. Світ ловив мене, та не впіймав. Харків: Фоліо, 2006. Ст. 526.

${ }^{26}$ Сковорода Г. Світ ловив мене, та не впіймав. Харків: Фоліо, 2006. Ст. 518. 
literature, specifically in poetry, "soul" and "heart" are in active use, mostly as an emotional center, but much less use in artistic creative work has "spirit", as it is often identified with "soul", although in theology these concepts are clearly differentiated. Apostle Paul writes in the Epistle to the Hebrews: "For the word of God is living, and active, and sharper than any two-edged sword, and piercing even to the dividing of soul and spirit, of both joints and marrow, and quick to discern the thoughts and intents of the heart" ${ }^{27}$ (Heb. 4, 2). "Spirit" is often meant "soul of soul".

In the works of B.-I. Antonych we observe a deep understanding of the specificity of the soul and heart by the poet. For example, in the poem "Advocatus diaboli" we read: "My soul has been stained by life and evil, but look into my heart" 28 . In the biblical texts, the concepts of soul and heart are often interchangeable, but from the lines above we draw a conclusion that in the author's understanding the heart is a higher substance than the soul, since God will judge man according to his own preference:

Then you'll place all my pride,

all my love, on the scales,

I'll look without fear, though I wasn't timid,

for my heart will prevail again ${ }^{29}$.

The soul is subjected to various negative influences more, while the heart is the sphere of divine possession. In many of his works Saint Yevahriy of Pontius speaks of the inner space, which is contained in every person. For him, it is a space of love and a space free from the sediment and mud of passions. This is the place of $\operatorname{God}^{30}$. The state of the human heart is projected on the whole man, so the poet takes care of that his heart was at peace with God, which results in harmony in the broadest sense of the word.

In the biblical sense, peace is a state opposite to war. For the Christian, peace is so great a good that Jesus Christ himself presented it to his apostles: "Peace (be) unto you" (Lk. 24, 36; Jn. 20, 19), "Peace I leave with you; my peace I give unto you" (Jn. 14, 27), "Peace (be) to this house" (Mt. 10, 12; Lk. 10, 5). In addition, most church worship services contain requests for peace: "Let us pray to the Lord in peace", "Let us pray

${ }^{27}$ Шпідлік Т. Духовність християнського Сходу / Пер. 3 італ. Мар'яни Прокопович. Львів: Видавництво ЛБА, 1999. Ст. 38.

28 Антонич Б. І. Повне зібрання творів / Передмова Миколи Ільницького; Упорядкування і коментарі Данила Ільницького. Львів: Літопис, 2009. Ст. 93.

29 Антонич Б. І. Повне зібрання творів / Передмова Миколи Ільницького; Упорядкування і коментарі Данила Ільницького. Львів: Літопис, 2009. Ст. 93.

${ }^{30}$ Грюн А. Пасхальна радість / Пер. 3 нім. Н. Лозинської. Львів: Місіонер, 2007. Ст. 122. 
to the Lord for peace from the heights and salvation of our souls", "Let us go out in peace". Peace is the state that a person aspires after an exhausting spiritual struggle against evil. A state of spiritual peace and joy is unknown to a man whose heart is overburden with passions.

G. Skovoroda and B.-I. Antonych thought on the issues of internal peace and harmony. The philosopher in "Friendly Talk about Peace of Soul" offers the following understanding of peace that leads to happiness: "[...] the top and blossom of your whole life is inner peace, heartfelt joy, spiritual fortitude. Direct the course of all your affairs here [...] As many of you are healthy, satisfied, dressed and calm, but I do not praise this peace this peace is earthly, it is known to everyone and deceives everyone. Here is the peace! - in the calm of thoughts, the joy of the heart, the animation of the soul. Here is the peace! Here are the bowels of happiness! This peace opens your mind a temple of calmness, dresses your soul in joy, satiates wheat flour and strengthens the heart" 31 .

B.-I. Antonych understands the spiritual peace as a harmony. Collection "The Great Harmony" witnesses that the poet aspired to peace and looked for ways of its comprehending. The Christian God is the highest harmony, the tuning fork on which man and the world are tuned. The poet realizes that "You need very little to reach happiness: Just some harmony" ("Amen"), "harmony in your heart - you do not need anything more" ("Naivety"); in "Litania" the "harmony of the soul" is identified with the caress of faith. B.-I. Antonych comes to the important recognition that the highest harmony is God, who is not only the source of the harmony of the human heart, but also the harmony of the cosmic, because "He gives melody to every thing". It is not easy to grasp harmony, however it is the privilege of only a heart which for its sake renounces the secular satisfaction, empty philosophizing, and is guided exceptionally by the will of God, which puts it higher than its selfish wishes:

But today I am ripe as in the summer,

I am done with my youthful pranks and jousting,

I have made my peace with God and the world, and have found perfect harmony in my heart ${ }^{32}$.

Despite all these outlook and ideological-thematic similarities of the works of Gregory Skovoroda and Bohdan-Igor Antonych, in our opinion, the image of Jesus Christ is the most eloquent unifying factor, which is cross-cuttingin the works of both poets. But Iryna Betko remarks that in "The Garden of Divine Songs" by Skovoroda God the Son is the

\footnotetext{
${ }^{31}$ Сковорода Г. Світ ловив мене, та не впіймав. Харків: Фоліо, 2006. Ст. 206.

32 Антонич Б. І. Повне зібрання творів / Передмова Миколи Ільницького; Упорядкування і коментарі Данила Ільницького. Львів: Літопис, 2009. Ст. 103.
} 
predominant meaning-making and meaning-holding symbol, as in "The Great Harmony" by Antonych God the Father is ${ }^{33}$.

All poems of the poet in which the image of the Creator God is central ("Musica noctis", "Te Deum laudamus", "Deus Magnificus", "Veni Creator", "Te Deum laudamus, 2", "Magnificat"), are united into the only thankful prayer in which the lyric hero praises the Lord, praises his grandeur, emphasizes his omnipotence and omnipresence.

Enthusiastic worship to the Creator is also present in Gregory Skovoroda, because the Ukrainian philosopher perceived nature as one of the sources of God-knowledge, and every thinking man, looking the beauty of the universe, gratefully bows to the One Who created it. The thinker is convinced that "everything lives and moves in God and by the power of God, we know everything only through God and in God", "God penetrates and holds all creation", "All creation follows afterthe guidance of the Creator [...] Who calls the breed of nightingales and blackbirds tothe forests and gardens, larks to the fields, and frogs to the waters and swamps? Who leads the rivers to the sea? Who attracts steel to a magnet? Who lifts the shivering flame up? It is our God who rules over everything and manages all in everything,"34. In this context, Mykola Ilnytskiy explains the phenomenon of Antonych's reverence for nature: "Antonych preached the philosophy of pantheism in the Skovoroda's sense, where nature thinks, where the spiritual source is dissolved in nature itself" ${ }^{35}$. A collection "The Book of the Lion" by Bohdan-Igor Antonych, in which the concept of beauty and the ugly is the cross-cutting theme and which is filled with natural and bestiary symbols (lion, fantastic sea creatures, sea, water, stone), which have their artistic manifestations in the works of Gregory Skovoroda, can serve as an artistic illustration of this thesis. Let remark that most characters in one way or another represent Christ or concentrate attention on various aspects of a person's spiritual life.

As already noticed, the image of the Second Person of God is dominant in the collection "The Garden of Divine Songs". Gregory Skovoroda sees not only the moral ideal in Jesus Christ, as some scholars are remarked, but also the Savior, the Redeemer, that is, completely God and completely Man.

33 Бетко І. Осмислення нумінозного досвіду в поезії Богдана-Ігоря Антонича. Бетко I. Українська релігійно-філософська поезія. Етапи розвитку. Katowice: Wydawnictwo Uniwersytetu Śląskiego, 2003. Ст. 190.

34 Чижевський Д. Філософія Г. С. Сковороди / Підготовка тексту, мовна редакція та вступна стаття Л. Ушкалова. Харків: Акта, 2003. Ст. 182-183.

35 Весни розспіваної князь. Слово про Антонича: Статті, есе, спогади, листи, поезії. Львів: Каменяр, 1989. Ст. 141. 
Oh Jesus! Oh my pleasure!

Do you live here? O joy of suffering ones!

Give me salvific healing in this passion,

Don't let medisappear forever! ${ }^{36}$.

In general, the entire collection "The Garden of Divine Songs" is imbued with important postulates of Christ's teaching, which, though indirectly, introduces the image of Christ into the work. For example, in the poem "Oh, you bird of the yellow", the author warns the reader against such sins as vanity and pride, because a person with such passions cannot grasp peace of mind:

Let those brains breaks off, who climbs high up, and I'll be quietly to myself

while the nice age, so all evil will pass me by,

I'll be happy $\operatorname{man}^{37}$.

As Christ preached humility, repeatedly gave humility lessons by his life, we understand from the work that the lyrical hero, practicing the simplicity, quietness, imitates his Teacher. In Antonych's poem "Sacred Simplicity" there are consonant motives:

Grand simplicity is

the highest perfection.

Naivety is sacred,

Smallness is the crowning.

This kind of a person is happy.

His road is clear:

like a child

In naivety he prays to God! $!^{38}$.

As already noticed, "Agnus Dei" is a landmark poem in the creative work of Bohdan-Igor Antonych, in which the poet veiledly speaks about the Passions of the Christand also introduces Eucharistic symbols in the text. In Gregory Skovoroda the theme of Christ's sufferings is revealed in the 7th song. The lyric hero empathizes with Christ, understands the weight and significance of His sacrifice:

Take me with you to the mountain path to the cross;

I am glad to live above the mountain;

I will throw the earth with my palm.

${ }^{36}$ Сковорода Г. Світ ловив мене, та не впіймав. Харків: Фоліо, 2006. Ст. 516.

${ }^{37}$ Сковорода Г. Світ ловив мене, та не впіймав. Харків: Фоліо, 2006. Ст. 525.

38 Антонич Б. І. Повне зібрання творів / Передмова Миколи Ільницького; Упорядкування і коментарі Данила Ільницького. Львів: Літопис, 2009. Ст. 99. 
Your death is my existence,

Your bile is the kind of sweets, oh Jesus!

Your severe wounds are my seal,

Your crown of thorns is the grace of glory to me,

This Yourabusive cross -

Is my praise and honor, Jesus! $!^{39}$

In the collections "The Garden of Divine Songs" and "The Great Harmony" poets appeal to the image of the Holy Spirit. According to Iryna Betko, "The Third Person of the Holy Trinity symbolizes spiritual insight; it is also the pledge of mystery. Antonych's lyrical hero is appealing with the request about the spiritual transformation to Her who would radically change his human nature. Spiritual transformation is a life-giving force, as well as the path that leads man to God as well as to oneself" ${ }^{40}$.

In the poetic works of Skovoroda, the Holy Spirit is viewed through the symbolic image of the dove: "The hearted dove announces peace to me" In general, the poet is convinced that the Holy Spirit can settle only in the heart from which the poison of sin has been eradicated. In "The Great Harmony," the Third Person of God takes a significant place. B.I. Antonych calls the Holy Spirit "Holy Dove", "Dove-Spirit", "Great Reaper of Souls". The lyrical hero asks the Holy Spirit for moral perfection, spiritual progress.

The image-symbol of the sun, which in Antonych's poetry is read as a symbol of the fullness of God's grace, is common to both poets:

You've placed a dreadful burden on my shoulders,

and I must carry it, without fail I must.

Dead things are the happiest - of all Saharan deserts

the fire of Your grace burns most intensely.

You've placed the sun on my shoulders ${ }^{42}$.

In Skovoroda, the sun is a symbol of the circle, and the circle is a "symbol that hides the infinite wheel of God's eternity", in the circle, "heavenly in the earthly, incorruptible in the corruptible is hidden".

The road, which in Ukrainian baroque literature is an allegory of the life path leading to eternity, is another unifying symbol for both poets. Gregory Skovoroda witnessed his convictions by a wandering way of life,

${ }^{39}$ Сковорода Г. Світ ловив мене, та не впіймав. Харків: Фоліо, 2006. Ст. 515.

40 Бетко І. Осмислення нумінозного досвіду в поезії Богдана-Ігоря Антонича. Бетко I. Українська релігійно-філософська поезія. Етапи розвитку. Катоwice: Wydawnictwo Uniwersytetu Śląskiego, 2003. Ст. $200-201$.

${ }^{41}$ Сковорода Г. Світ ловив мене, та не впіймав. Харків: Фоліо, 2006. Ст. 524.

42 Антонич Б. І. Повне зібрання творів / Передмова Миколи Ільницького; Упорядкування і коментарі Данила Ільницького. Львів: Літопис, 2009. Ст. 85. 
a renunciation of a constant settlement, of his own family, that is, of everything that would connect his spirit with earthly affairs. Bohdan-Igor Antonych in his poem "Liber peregrinorum" allegorically portrays the instability of human life, using the image of the road.

\section{CONCLUSIONS}

Trying to understand the outlook features of Bohdan-Igor Antonych, we find many common features with St. Francis of Assisi, who "saw the inner beauty of things and in the creation looked for the Creator" ${ }^{\text {" }}$. Besides comprehending the divine omnipresence, the poet had a similar understanding of death as St. Francis; he has the same subtle sense of music, the same ecstatic love for life.

Taking into account the poetic inheritance of Gregory Skovoroda and Bohdan-Igor Antonych, we come to the conclusion that there are many tangent moments in the world outlook and way of artistic thinking of poets. The artists deeply comprehended the inner life of man, artistically elaborated on the topics of purity of heart, the spiritual peace which they aspired so ardently. Both poets touched the problem of a deep personal connection with God, of the search of Him in all things, and first of all in the pages of Scripture. In "The Garden of Divine Songs" and in "The Great Harmony", the receptive models of the Three Divine Persons - God the Father, Son and Holy Spirit - are presented, though sometimes with different artistic priorities. Despite all these outlook and ideologicalthematic similarities of the works of Gregory Skovoroda and Bohdan-Igor Antonych the image of Jesus Christ is the most eloquent unifying factor, which is cross-cuttingin the works of both poets.

The themes of the great Christian holidays - Christmas, Easter, Ascension, and the Descent of the Holy Spirit - became common for poets. Besides that, many common features in the artistic elaboration of natural and bestiary symbols (lion, fantastic sea creatures, sea, water, and stone), the interpretation of which witnesses the deep artists' dialogue with the Bible, are outlined. Some poetic works of artists are related even by genre, because it is known that the poems, which were included in the collection "The Garden of Divine Songs", G. Skovoroda called "songs", and in B.I. Antonych is a series of works that the author has marked as "songs" ("Song about eternal youth", "Song of the competitors", "Song of the wanderer", "Song about the premature light").

${ }^{43}$ Стікко М. Святий Франциск з Асижу / Пер. з італ. Н. Липки. Жовква: Місіонер, 2010. Ст. 281. 


\section{SUMMARY}

The poetic creative work of B.-I. Antonych may serve as an artistic illustration of the Francis Assisi's postulates, because he is the author of "Hymn to Life", and works from the collection "The Great Harmony" "Deus Magnificus" ("God Magnificent"), "Te Deum Laudamus" ("We Praise Thee, O Lord"), "Magnificat" ("Glorification") should be considered as the only great glory-word of divine omnipresence. In Francis of Assisi and Bohdan-Igor Antonych we retrace common features in the perception of Jesus Christ. As in the perception of St. Francis of Assisi and Bohdan-Igor Antonych God, merciful and gentle, not fair and punishing, is at the forefront.

Gregory Skovoroda and Bohdan-Igor Antonych lived and worked in different time and cultural periods, but between them there is a certain spiritual connection, which is traced in similar views on God, the world, man, nature. The common point of contact between the two artists was the "philosophy of the heart", which was theoretically substantiated by Gregory Skovoroda, and Bohdan-Igor Antonych offered its artistic reception in his poetic collections. G. Skovoroda and B.-I. Antonych clearly distinguishes the concepts of "spirit", "soul", "heart". The purity of the heart in both artists is often associated with the theme of death. "The Garden of Divine Songs" and "The Great Harmony" are collections of spiritual lyricism, because the search for a deep personal connection with God, the experience of which is comprehended through the Scripture and the Liturgy, is a leading theme in them.

\section{REFERENCES}

1. Антонич Б. І. Повне зібрання творів / Передмова Миколи Ільницького; Упорядкування і коментарі Данила Ільницького. Львів: Літопис, 2009. 968 с.

2. Бетко I. Осмислення нумінозного досвіду в поезії БогданаІгоря Антонича. Бетко I. Украӥнська релігійно-філософська поезія. Eтапи розвитку. Katowice: Wydawnictwo Uniwersytetu Śląskiego, 2003. Ст. $174-209$.

3. Весни розспіваної князь. Слово про Антонича: Статті, есе, спогади, листи, поезії. Львів: Каменяр, 1989. 430 с.

4. Грюн А. Пасхальна радість / Пер. 3 нім. Н. Лозинської. Львів: Місіонер, 2007. $176 \mathrm{c}$.

5. Іспит сумління з учителями християнської духовності / Пер. 3 пол. О. Мандрика. Львів: Свічадо, 2014. 80 с.

6. Насмінчук Г. Біблійна естетика у творчості Б.-І. Антонича. Біблія і культура: Збірник наукових статей. Вип. І. Чернівці: Рута, 2000. Ст. $83-84$. 
7. Погорілий С. Символи у Сковороди. Сучасність. 1973. Ч. 3 (147). Ст. $17-24$.

8. Рацінгер Йосиф (Венедикт XVI). Ісус з Назарету. Книга друга. Від в'їзду в Єрусалим до Воскресіння / Пер. 3 нім. І. Терзової. Жовква: Місіонер, 2011. 288 с.

9. Ронкі Е. Закоханий і здивований Бог / Пер. з італ. К. Зінченко. Львів: Свічадо, 2015. 80 с.

10. Сковорода Г. Світ ловив мене, та не впіймав. Харків: Фоліо, 2006. $607 \mathrm{c}$.

11. Стікко М. Святий Франциск з Асижу / Пер. 3 італ. Н. Липки. Жовква: Місіонер, 2010. 330 с.

12. Творенія иже во святихъ отца нашего Василія Великаго, Архіепископа Кесаріи Каппадокійскія. У 3 т. Т. 1. Санкт-Петербургъ: Книгоиздательство П. П. Сойкина, 1911. 648 с.

13. Тиллих П. Систематическое богословие. СПб.: Алетейя, 1998. $488 \mathrm{c}$.

14. Токмань Г. Збірка Б.-І. Антонича "Велика гармонія" у діалозі з екзистенціальним богослов'ям. Слово $і$ час. 2002. № 12.Ст. $41-53$.

15. Чижевський Д. Філософія Г. С. Сковороди / Підготовка тексту, мовна редакція та вступна стаття Л. Ушкалова. Харків: Акта, 2003. $432 \mathrm{c}$.

16. Шпідлік Т. Духовність християнського Сходу / Пер. 3 італ. Мар'яни Прокопович. Львів: Видавництво ЛБА, 1999. 496 с.

17. Шпідлік Т. Мистецтво очищувати серце / Пер. 3 італ. А. Маслюх. Львів: Свічадо, 2005. 72 с.

\section{Information about the author: \\ Dmytriv I. I.,}

Candidate of Philology, Associate Professor at the Department of Ukrainian Literature and Theory of Literature, Drohobych State Pedagogical University named after Ivan Franko 24, Taras Shevchenko str., Drohobych, 82100, Ukraine 